Note

\title{
Chemotaxis detection towards chlorophenols using video processing analysis
}

\author{
E. Okada ${ }^{\mathrm{a}, 1}$, M. Nisenbaum ${ }^{\mathrm{b}, * 1}$, J. Martínez Arca $^{\mathrm{c}}$, S.E. Murialdo ${ }^{\mathrm{d}}$ \\ a Consejo Nacional de Investigaciones Científicas y Técnicas (CONICET), Buenos Aires, Argentina \\ b Grupo de Ingeniería Bioquímica (GIB), Departamento de Ingeniería Química y en Alimentos, Facultad de Ingeniería, Universidad Nacional de Mar del Plata, Juan B Justo \\ 4302, Mar del Plata y CONICET, Mar del Plata, Buenos Aires, Argentina \\ c Instituto de Investigaciones Científicas y Tecnológicas en Electrónica, Laboratorio de Bioingeniería, Departamento de Ingeniería Electrónica, Facultad de Ingeniería, \\ Universidad Nacional de Mar del Plata y CONICET, Juan B Justo 4302, Mar del Plata, Buenos Aires, Argentina \\ d Grupo de Ingeniería Bioquímica (GIB), Departamento de Ingeniería Química y en Alimentos, Facultad de Ingeniería, Universidad Nacional de Mar del Plata, Juan B Justo \\ 4302, Mar del Plata y La Comisión de Investigaciones Científicas de la Provincia de Buenos Aires (CIC), Buenos Aires, Argentina
}

\section{A R T I C L E I N F O}

\section{Keywords:}

Chlorophenols

Mixed culture

Chemotaxis

Video processing analysis

\begin{abstract}
A B S T R A C T
To our knowledge, this communication is the first report of chemotaxis towards chlorophenols by any bacteria. We used a recently published method based on the agarose in-plug assay combined with video processing analysis and we also present a new index of bacterial mean speed for these assays.
\end{abstract}

Chemotaxis is the movement of bacterial cells towards or away from chemicals (Eisenbach and Lengeler, 2004; Marx and Aitken, 2000; Pandey and Jain, 2002; Tso and Adler, 1974) with the aim of finding ideal conditions for growth and survival (Paul et al., 2006). Bacterial chemotaxis may have a significant impact on the structure and function of bacterial communities (Law et al., 2005; Tolker-Nielsen et al., 2000). There is sufficient evidence demonstrating that positive chemotaxis has the potential to enhance the bacterial degradation of organic pollutants in contaminated environments (Krell et al., 2013) in which the pollutants are distributed heterogeneously, generally by association with non-aqueous phases (Marx and Aitken, 2000). Several microorganisms, showing chemotactic responses towards different pollutants, have been isolated and characterized (Paul et al., 2005). By bringing microorganisms closer to sources of higher pollutant concentrations, chemotaxis could also increase the concentration gradient, the corresponding rate of mass transfer and consequently the overall rate of biodegradation (Krell et al., 2013; Lacal et al., 2013; Meng et al., 2017).

To date, most of the reported chemotaxis assays are primarily qualitative, as the swarm plate assay (Adler, 1966) and the agarose-inplug method (Yu and Alam, 1997). Although they are easy to use, these methods are limited in the accurate control of chemical gradients, low sensitivity or have long analytical times (Jeong et al., 2013). In addition, bacterial growth in certain toxics as the sole source of carbon and energy leads to slow bacterial growth and low cell yields (Johnsen et al., 2002), which makes it difficult to detect chemotactic responses towards these chemicals. A large amount of phenolic compounds, which include chlorophenols (CPs), are discharged through effluents from a variety of industries (Jiang et al., 2013; Kılıç, 2009). Due to their high toxicity to the environment and health, these compounds are categorized as priority chemicals by the U.S. Environmental Protection Agency (EPA) (Lei et al., 2006). Chlorophenols (CPs) are used worldwide in wood preservation, pesticides, fungicide and explosives (United States Environmental Protection Agency, 1980). One of the most commonly used CP is pentachlorophenol (PCP) a synthetic organochlorine compound that was first manufactured commercially in 1936 and is still used primarily as a wood preservative (Eisler, 1989). This compound is fetotoxic, teratogenic, it has caused numerous occupational illnesses and deaths and has had significant adverse effects on domestic animals (Eisler, 1989). In the production of PCP, it is common to obtain other CPs as by products, such as $2,4,6$-trichlorophenol $(2,4,6$ TCP), 2,3,5,6 tetrachlorophenol $(2,3,5,6-\mathrm{TeCP})$ and $2,3,5$ trichlorophenol (2,3,5 TCP) (Middaugh et al., 1993). The removal of PCP from industrial wastewaters before their discharge is mandatory ( $\mathrm{Lu}$ et al., 2012). However, its extensive use has led to the pollution of soil and groundwater.

Several physico-chemical and biological methods have been used for removal of phenolic compounds from the environment (Arora and Bae, 2014; Chauhan et al., 1999; Estevinho et al., 2006; Jianlong et al.,

\footnotetext{
* Corresponding author at: Juan B Justo 4302, 7600 Mar del Plata, Buenos Aires, Argentina.

E-mail address: melinan@fi.mdp.edu.ar (M. Nisenbaum).

${ }^{1}$ Both authors participate equally in the present work.
} 


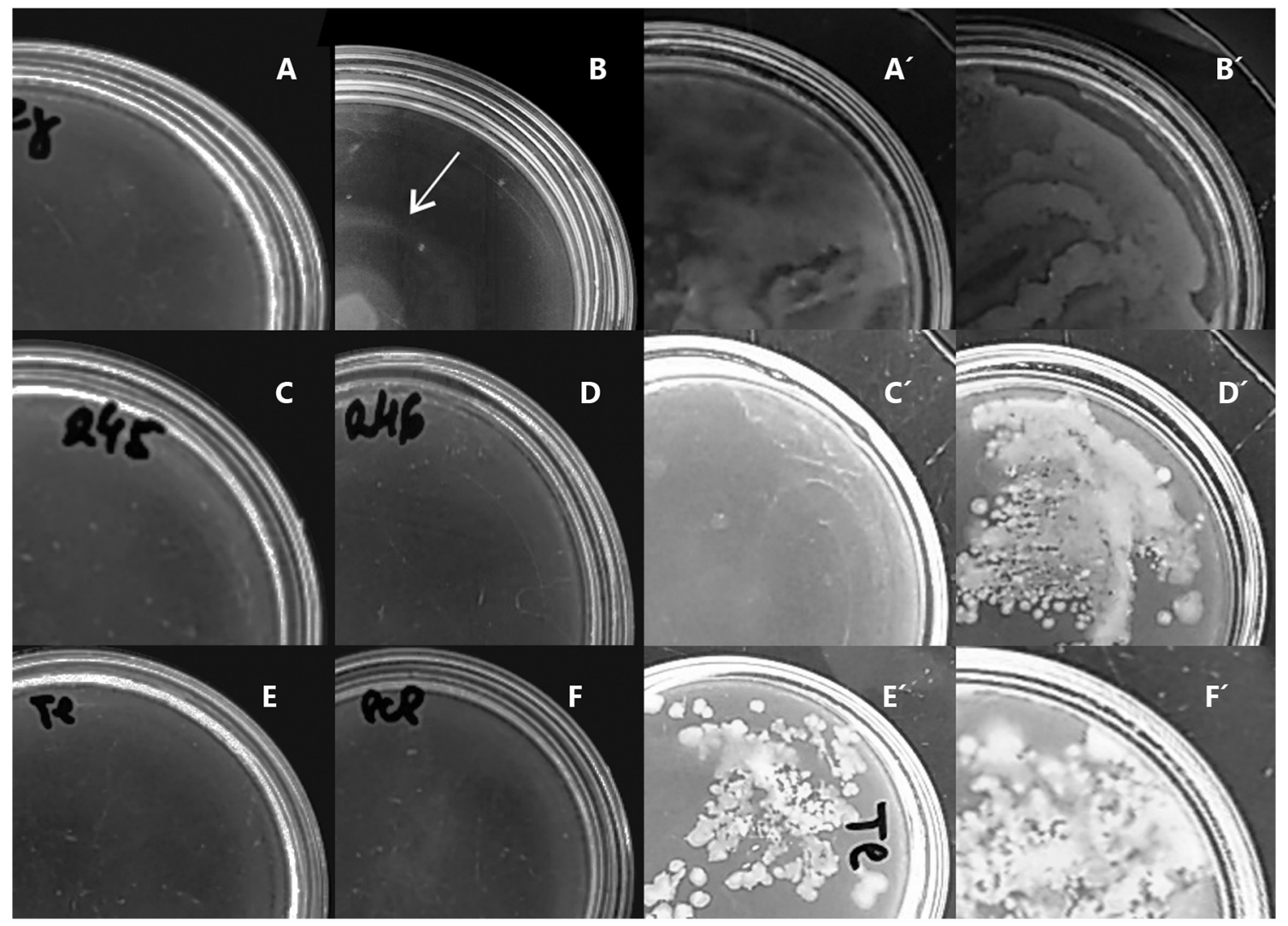

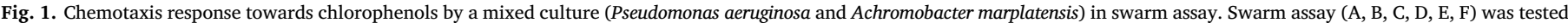

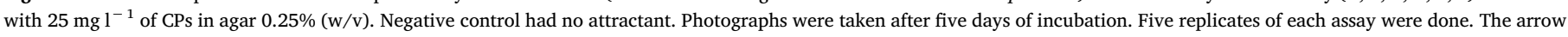

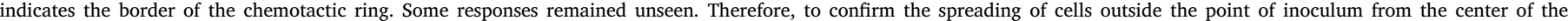

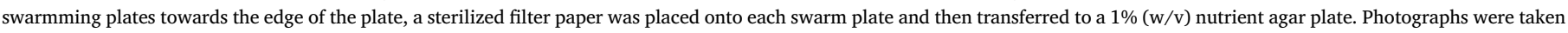

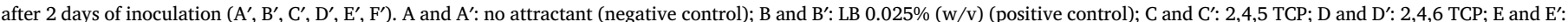
2,4,5,6 TeCP; F and $F^{\prime}$ : PCP.
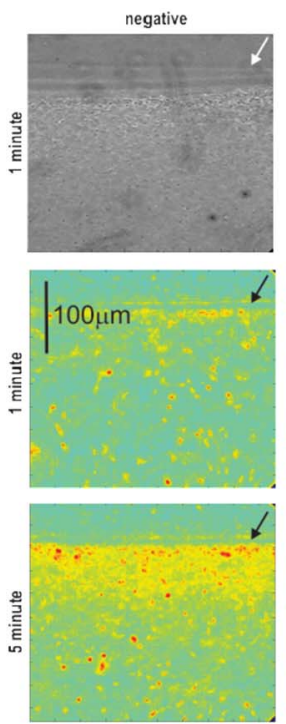

LB
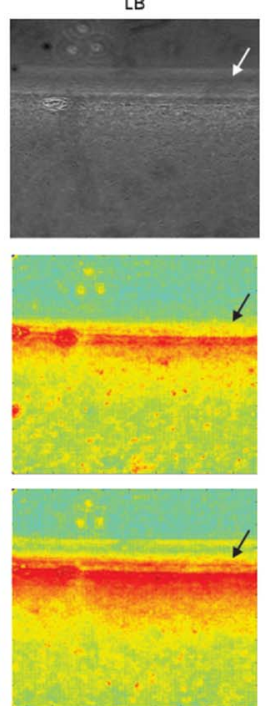

PCP
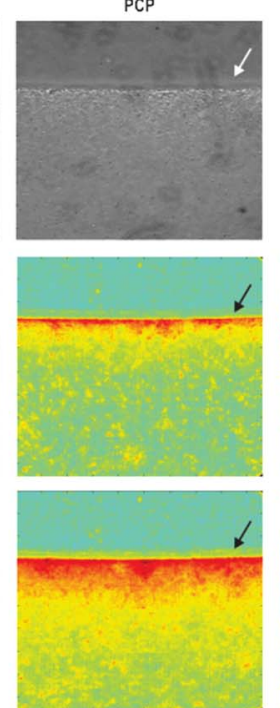

$2,4,5$ TCP
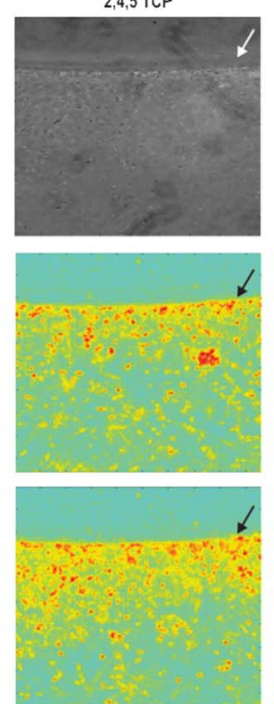

$2,4,5,6 \mathrm{TeCP}$
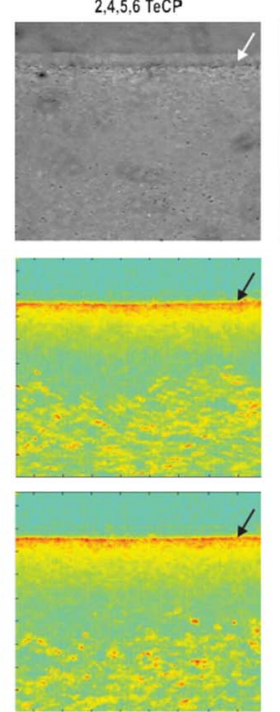

$2,4,6$ TCP
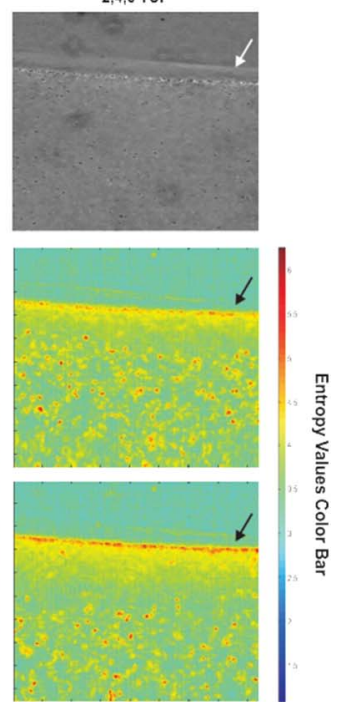

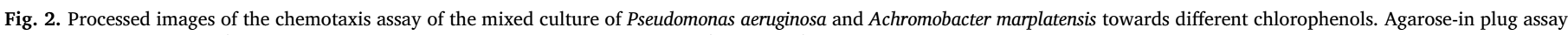

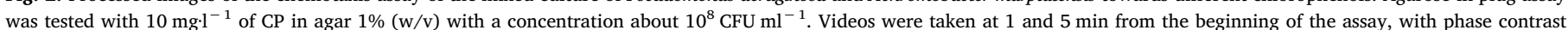

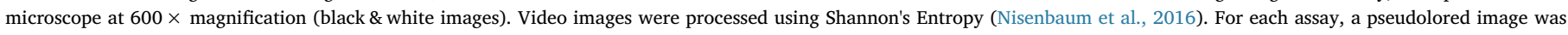

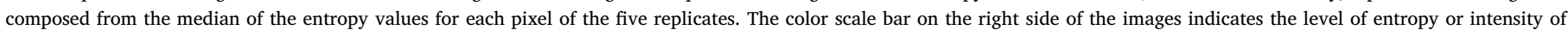

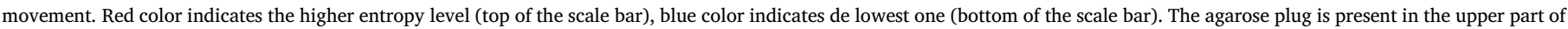

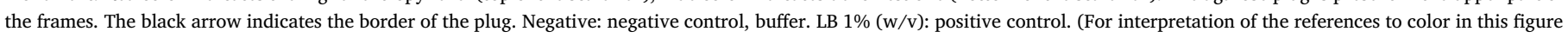
legend, the reader is referred to the web version of this article.) 
Table 1

Bacterial Motility Index $\left(M_{(i)}\right)$, Attraction Index $\left(A_{(i)}\right)$ and Average Speed $\left(V_{(i)}\right)$ for different chlorophenols. $M_{(i)}$ and $A_{(i)}$ were determined in the first zone next to the plug $(0-31.5 \mu \mathrm{m})$ in each processed image after $5 \mathrm{~min}$ from the beginning of the assay. Values obtained for the negative control plug (buffer) in each time were subtracted from the values of the tested chemoeffectors. LB: positive control. Positive value: attractant. Negative value: repellent. $i$ : attractant of the assay. The presented values are the median of the replicates $(N=5)$ with the respective standard deviations $( \pm)$.

\begin{tabular}{llll}
\hline$i$ & $M_{(i)}$ & $A_{(i)}$ & $V_{(i)}\left(\mu \mathrm{m} \mathrm{s}^{-1}\right)$ \\
\hline Buffer & 0 & 0 & $18.01 \pm 5.34$ \\
LB & $0.77 \pm 0.059$ & $3.57 \pm 0.21$ & $28.76 \pm 3.11$ \\
PCP & $0.50 \pm 0.063$ & $2.95 \pm 0.276$ & $38.67 \pm 7.07$ \\
$2,3,5,6 \mathrm{TeCP}$ & $0.31 \pm 0.036$ & $2.92 \pm 0.178$ & $10.18 \pm 0.64$ \\
$2,4,6 \mathrm{TCP}$ & $0.24 \pm 0.028$ & $2.84 \pm 0.492$ & $42.72 \pm 7.82$ \\
$2,4,5$ TCP & $-2.24 \pm 0.3425$ & $-1.18 \pm 0.425$ & $13.91 \pm 4.08$ \\
\hline
\end{tabular}

2000; Mathialagan and Viraraghavan, 2009; Abdel-Ghani et al., 2013; Yang and Lee, 2008), including storage in land-fill sites, incineration and abiotic degradation processes such as photodecomposition (McAllister et al., 1996). However, bacterial degradation is considered the most cost-effective and eco-friendly remediation method. Many chlorinated compounds are biodegradable by a wide range of bacterial strains, some of which have been isolated and characterized for potential bioremediation applications (Bhushan et al., 2000; Chin Wang et al., 2000; Durruty et al., 2011a; Haddadi and Shavandi, 2013; McAllister et al., 1996; Middaugh et al., 1993; Murialdo et al., 2003; Wolski et al., 2006). Additionally, the metabolic pathways and degradation of CPs have been studied in bacteria and the genes and enzymes involved have been identified and characterized (Alva and Peyton, 2003; Arora and Bae, 2014; Bonfá et al., 2013; Haddadi and Shavandi, 2013; Quilty, 1998; Wang et al., 2014). In spite of this, to our knowledge, there are few communications about chemotaxis towards phenolic compounds (Arora et al., 2015; Bhushan et al., 2000; Paul et al., 2006; Pham and Parkinson, 2011; Sarand et al., 2008). However, these studies have not included chlorophenols. Therefore, the main objective of this study was to characterize the chemotactic response towards CPs by a mixed culture composed of Pseudomonas aeruginosa and Achromobacter marplatensis. We were able to determine this response using the new method of video processing analysis recently published by our group (Nisenbaum et al., 2016) and develop a new tool to determine the mean velocity of the response.

The mixed culture composed was isolated from contaminated PCP soils (Gomila et al., 2011; Murialdo et al., 2003). The culture was cultivated in a minimum liquid medium (MM) composed by the following inorganic salts (mg. $\mathrm{l}^{-1}$ ): $2.93 \mathrm{PO}_{4} \mathrm{~K}_{2} \mathrm{H}, 0.77 \mathrm{PO}_{4} \mathrm{H}_{2} \mathrm{~K}$ (Sigma), $2.25 \mathrm{NH}_{4} \mathrm{NO}_{3}, 0.45 \mathrm{MgSO}_{4} .7 \mathrm{H}_{2} \mathrm{O}$ (Anedra); and $15 \mathrm{mg} . \mathrm{l}^{-1}$ of each $\mathrm{CP}$ in a mixture as a sole carbon source, at $\mathrm{pH}$ 7. The flasks were kept at $25{ }^{\circ} \mathrm{C}$ in the dark to avoid photo-decomposition of CPs.
Before the chemotaxis assay, an aliquot of the culture at the end of the exponential phase was transferred to fresh MM with $1 \%(\mathrm{w} / \mathrm{v})$ glutamate and $50 \mathrm{mg} \mathrm{l}^{-1} \mathrm{PCP}$. After $24 \mathrm{~h}$ incubation with a constant orbital shaking at $25^{\circ} \mathrm{C}$, the cell culture was centrifuged at $3000(\mathrm{~g})$ for $20 \mathrm{~min}$. The pellet was re-suspended in motility buffer (0.1 mM EDTA and $10 \mathrm{mM} \mathrm{PO}_{4} \mathrm{~K}_{3}, \mathrm{pH}$ 7) without a carbon source for $24 \mathrm{~h}$ at constant temperature $\left(25^{\circ} \mathrm{C}\right)$.

We first tested the chemotactic response towards CPs with the traditional swarm assay (Adler, 1966). Three $\mu$ of $P$. aeruginosa and A. marplatensis culture was inoculated in the center of the petri dish capsules with $0.2 \% \mathrm{p} / \mathrm{v}$ agar in motility buffer with $0.025 \% \mathrm{w} / \mathrm{v}$ LB (positive control), without any attractant substance (negative control) or with $25 \mathrm{mg} \cdot \mathrm{l}^{-1}$ of PCP, 2,4,6 TCP, 2,3,5,6 TeCP or 2,3,5 TCP. The dishes were incubated at $25^{\circ} \mathrm{C}$ in a $100 \%(\mathrm{v} / \mathrm{v})$ humidity chamber (Darnton et al., 2010) and were examined every $24 \mathrm{~h}$. Photographs were taken with a charge-coupled device (CCD) camera (Cyber-Shot Sony DSC-W5), observing the plate illuminated with white light from the bottom (Parkinson, 2007). The assay was performed with five independent experiments for each compound, and three replicates for each experiment.

The swarm assay (Fig. 1, A to F) did not show an accurate and reproducible response when using chlorophenols as attractants. This could be due to a low biomass yield when the cells were grown with pentachlorophenol (PCP) as a sole carbon source (Murialdo et al., 2003), which difficults to visualization of the chemotactic ring. To confirm the cell spreading from the inoculation point to the outside edge of the swarm plates, a sterilized filter paper was placed onto the swarm plates at the end of the incubation period (5 days), and transferred to a $1 \%(\mathrm{w} / \mathrm{v}) \mathrm{LB}$ agar plate. After 2 days of incubation (Fig. 1, $\mathrm{A}^{\prime}$ to $F^{\prime}$ ) the spreading of bacterial cells was evidenced in all the plates except when using 2,4,5 TCP as attractant.

In some replicates, the negative control plates also presented weak chemotactic rings, even though it was of the best purity available. It was confirmed when transferring cells onto a filter paper blot to the LB $1 \%(\mathrm{w} / \mathrm{v})$ agar plate for getting visible colonies after the incubation $\left(\mathrm{A}^{\prime}\right)$ and infering the spreading from the point of inoculation. The same result, of weak chemotactic response towards the agar as negative control, was reported by Nisenbaum et al. (2013), and Lanfranconi et al. (2003) and Bhushan et al. (2000). According to these results, chemotactic responses towards CPs could not be assured by using this method.

Therefore, the PC chemotactic response was then tested using the agarose in-plug assay (Yu and Alam, 1997) combined with a video processing analysis recently published by our group (Nisenbaum et al., 2016). The chemotaxis chamber was made with two plastic strips glued to a slide. A five $\mu \mathrm{l}$ plug of high purity agar $1 \%(\mathrm{w} / \mathrm{v})$ dissolved in motility buffer was placed in the center of the chamber. The agar plug contained $10 \mathrm{mg} \cdot 1^{-1}$ of PCP, 2,4,6 TCP, 2,3,5,6 TeCP or 2,3,5 TCP as

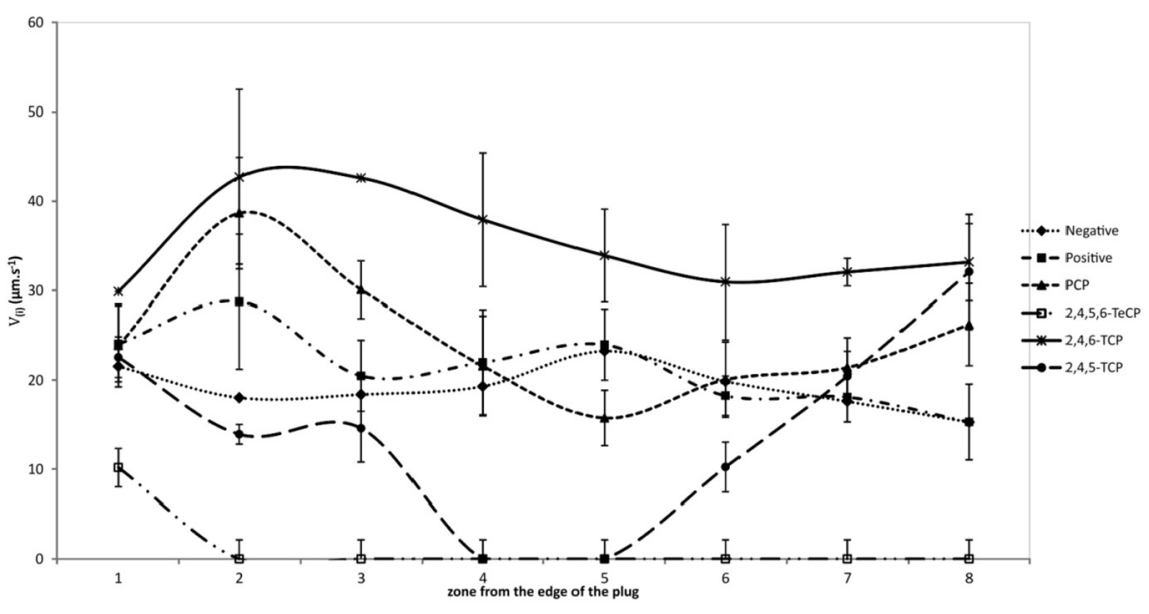

Fig. 3. Average speed values $\left(V_{i}\right)$ of the bacteria placed at different distances from the plug with the tested chlorophenols. The (V_i) was calculated within each subzone (s) $\left(V(s, i)=\frac{\sum_{n}^{N}=1\left(\frac{x}{t}\right)_{n}}{N}\right.$; Eq. (1)) by measuring the displacement (distance, $\mathrm{x}$ ) among the consecutive frames between the centroid of a bacterium in any direction. Those bacteria that moved outside the field of view were not considered. $N=50$. 
attractants, $1 \%(\mathrm{p} / \mathrm{v}) \mathrm{LB}$ (positive control) or no attractant (negative control). The bacterial suspension $\left(\mathrm{OD}_{600}=0.2\right.$, about $\left.10^{8} \mathrm{CFU} \mathrm{ml}{ }^{-1}\right)$ was then incorporated into the chamber. Bacterial motility in the surrounding areas of the plug was observed with an optical microscope (Olympus BH2) at $600 \times$, equipped with a phase contrast filter. The assay was performed with five independent experiments for each compound, and three replicates for each experiment.

Twenty second-videos were recorded at 1 and $5 \mathrm{~min}$ after the inoculation using a CCD camera (Cyber-Shot Sony DSC-W5) with an optical zoom of 1.7, in the B \& W mode, at 30 frames per second. Captured images in MPEG format were processed as shown in Nisenbaum et al. (2016) using Shannon Entropy (Shannon, 1948) as a descriptor. The active region was divided into subzones of $31.5 \mu \mathrm{m}$ for further calculations. The independent experiments were used to compute an entropy value for each pixel and the final entropy was estimated as the median of the processed values. The final value of the entropy was used to assemble the pseudolored image of the assay (Fig. 2). As a measure of the reliability of measurements the Intraclass Correlation Coefficient (ICC) (Shrout and Fleiss, 1979) was performed on Entropy values in the five replicates of each assay resulting high values of Agreement (0.985).

Motility Index $\left(M_{(i)}\right)$ (quantity of movement) and Attraction Index $\left(A_{(i)}\right)$ was calculated as described elsewhere (Nisenbaum et al., 2016) from the 5 min images (Table 1). The $A(i)$ determines the chemoeffector as attractant (positive value) or repellent (negative value), and its absolute value compares the intensity of the bacterial population response.

In metabolism-dependent taxis, the physiological relevance of chemo-attraction to pollutants lies in the fact that these compounds serve as carbon and energy sources (Krell et al., 2013; Sarand et al., 2008). The chemotactic response of this mixed culture of $P$. aeruginosa and $A$. marplatensis supports this statement since previous laboratory studies have shown that the strains are able to degrade PCP, 2,4,6-TCP and 2,3,5,6-TeCP as the only source of carbon and energy employing single $\mathrm{CP}$ or the CPs mixture. This work opens the possibilities for further studies to correlate the attraction towards CPs with catabolization rate, reported previously in Durruty et al. (2011b).

From the tracking of the bacteria in the areas near the plug, we determined a new index of bacteria mean speed $\left(V_{(s, i)}\right)$ for further characterization of the chemotactic response (Eq. (1)). The $V_{(s, i)}$ was calculated within each subzone $(s)$ by measuring the displacement (distance, $x$ ) among the consecutive frames between the centroid of a bacterium, in any direction. Those bacteria that moved outside the field of view were not considered. Then, the average of the rates obtained with each bacterium per zone was calculated as:

$V(s, i)=\frac{\sum_{n=1}^{N}\left(\frac{x}{t}\right)_{n}}{N}$

where $\left(V_{(s, i)}\right)$ is the average speed, $i$ denotes the attractant in the plug, $s$ corresponds to an entropy image subzone, $s=1,2, \ldots 8, n=1,2, \ldots N$, $N=50$ were $N$ is the number of the bacteria in subzone $s$ of image $i$; $\mathrm{x}=$ distance in $\mu \mathrm{m}$ and $t=$ time in seconds. Index values for each subzone were computed as the average over the replicates of each experiment.

The mean speed values for all the assays, except for the negative control, were higher next to the plug and then decreased in the areas further away from it (Fig. 3). Table 1 shows the highest bacterial speeds next to the plug for all the tested compounds. In the positive response towards 2,4,6-TCP and PCP, the mean speed of the bacteria $\left(V=42.72 \mu \mathrm{m} \cdot \mathrm{s}^{-1}\right.$ and $V=38.67 \mu \mathrm{m} \cdot \mathrm{s}^{-1}$ respectively) was much higher than in the negative control $\left(V=18.01 \mu \mathrm{m} \cdot \mathrm{s}^{-1}\right)$. When analyzing 2,3,5,6 TeCF, the average bacterial speeds were very low $\left(V=10.18 \mu \mathrm{m} \cdot \mathrm{s}^{-1}\right)$ in all the areas of the image. This, along with the low $M_{(i)}$ (Table 1), could be the result of a high amount of moving bacteria with slow displacement. The mild activity observed towards 2,3,5,6 TeCF could be related to the chloro-substitution patterns, where chlorophenols having 2,4- or 2,6 chloro-substitution patterns were better substrates than 3,5-substituted chlorophenols (Murialdo et al., 2003). Consequently, bacteria could be less active or have a higher mortality in the area near the plug. This effect was more accentuated for the plug with 2,4,5 TCP $\left(V=13.91 \mu \mathrm{m} \cdot \mathrm{s}^{-1}\right)$, where the bacterial mean speed decreased to a greater extent than in the negative plug (Fig. 3). 2,4,5 TCP is a meta-substituted CP and, therefore, it is more recalcitrant than the other CPs. Moreover, the mixed culture is not able to use this CP as a carbon source (Murialdo et al., 2003).

To the best of our knowledge, this is the first report of bacterial chemotaxis studies employing PCP, 2,4,6-TCP, 2,4,5 TCP and 2,3,5,6$\mathrm{TeCP}$ as attractant or repellent. Chemotaxis plays an important role in the biodegradation of other pollutants such as naphthalene, nitroaromatic compounds and chloroaromatic (Pandey and Jain, 2002; Bhushan et al., 2004; Parales, 2004). Thus, the capacity of $P$. aeruginosa and $A$. marplatensis to degrade and move positively towards CPs might help enhance the degradation of these recalcitrant compounds which is a helpful trait in bioremediation processes.

We thank CIC and CONICET for the fellowships, grants and salaries, S. Murialdo is a researcher of CIC. This work was supported by National University of Mar del Plata (15G/485 ING491/17 and 15/G492 ING498/17), MINCYT (PICT-2016-2087) and CIC (PIT-BA-2016).

\section{References}

Abdel-Ghani, N.T., El-Chaghaby, G.A., Zahran, E.M., 2013. Pentachlorophenol (PCP) adsorption from aqueous solution by activated carbons prepared from corn wastes. Int. J. Environ. Sci. Technol. http://dx.doi.org/10.1007/s13762-013-0447-1. Adler, J., 1966. Chemotaxis in bacteria. Science 153, 708-716.

Alva, V.A., Peyton, B.M., 2003. Phenol and catechol biodegradation by the haloalkaliphile Halomonas campisalis: influence of $\mathrm{pH}$ and salinity. Environ. Sci. Technol. 37, 4397-4402. http://dx.doi.org/10.1021/es0341844.

Arora, P.K., Bae, H., 2014. Bacterial degradation of chlorophenols and their derivatives. Microb. Cell Factories 13, 31. http://dx.doi.org/10.1186/1475-2859-13-31.

Arora, P.K., Jeong, M., Bae, H., 2015. Chemotaxis away from 4-Chloro-2-nitrophenol, 4Nitrophenol, and 2,6-Dichloro-4-nitrophenol by Bacillus subtilis PA-2. J. Chem. 2015, 1-4. http://dx.doi.org/10.1155/2015/296231.

Bhushan, B., Samanta, S.K., Chauhan, A., Chakraborti, A.K., Jain, R.K., 2000. Chemotaxis and biodegradation of 3-methyl- 4-nitrophenol by Ralstonia sp. SJ98. Biochem. Biophys. Res. Commun. 275, 129-133. http://dx.doi.org/10.1006/bbrc.2000.3216.

Bhushan, B., Halasz, A., Thiboutot, S., Ampleman, G., Hawari, J., 2004. Chemotaxismediated biodegradation of cyclic nitramine explosives RDX, HMX, and CL-20 by Clostridium sp. EDB2. Biochem. Biophys. Res. Commun. 316, 816-821. http://dx. doi.org/10.1016/j.bbrc. 2004.02.120.

Bonfá, M.R.L., Grossman, M.J., Piubeli, F., Mellado, E., Durrant, L.R., 2013. Phenol degradation by halophilic bacteria isolated from hypersaline environments. Biodegradation 24, 699-709. http://dx.doi.org/10.1007/s10532-012-9617-y.

Chauhan, S., Yankelevich, E., Bystritskii, V.M., Wood, T.K., 1999. Degradation of 2,4,5trichlorophenol and 2,3,5,6-tetrachlorophenol by combining pulse electric discharge with bioremediation. Appl. Microbiol. Biotechnol. 52, 261-266. http://dx.doi.org/ $10.1007 /$ s002530051519.

Chin Wang, C., Mei Lee, C., Jen Lu, C., Shang Chuang, M., Zong Huang, C., 2000. Biodegradation of 2,4,6-trichlorophenol in the presence of primary substrate by immobilized pure culture bacteria. Chemosphere 41, 1873-1879. http://dx.doi.org/10. 1016/S0045-6535(00)00090-4.

Darnton, N.C., Turner, L., Rojevsky, S., Berg, H.C., 2010. Dynamics of bacterial swarming. Biophys. J. 98, 2082-2090. http://dx.doi.org/10.1016/j.bpj.2010.01.053.

Durruty, I., Okada, E., González, J.F., Murialdo, S.E., 2011a. Degradation of chlorophenol mixtures in a fed-batch system by two soil bacteria. Water SA 37, 547-552. http://dx. doi.org/10.4314/wsa.v37i4.13.

Durruty, I., Okada, E., González, J.F., Murialdo, S.E., 2011b. Multisubstrate monod kinetic model for simultaneous degradation of chlorophenol mixtures. Biotechnol. Bioprocess Eng. 16, 908-915. http://dx.doi.org/10.1007/s12257-010-0418-z.

Eisenbach, M., Lengeler, J.W., 2004. Chemotaxis. Imperial College Press.

Eisler, R., 1989. Pentachlorophenol Hazards to Fish, Wildlife, and Invertebrates: A Synoptic Review. Laurel, MD. 20708http://dx.doi.org/10.5962/bhl.title.11357.

Estevinho, B.N., Ratola, N., Alves, A., Santos, L., 2006. Pentachlorophenol removal from aqueous matrices by sorption with almond shell residues. J. Hazard. Mater. 137, 1175-1181. http://dx.doi.org/10.1016/j.jhazmat.2006.04.001.

Gomila, M., Tvrzova, L., Teshim, A., Sedlacek, I., Gonzalez-Escalona, N., Zdrahal, Z., Sedo, O., Gonzalez, J.F., Bennasar, A., Moore, E.R.B., Lalucat, J., Murialdo, S.E., 2011. Achromobacter marplatensis sp. nov., isolated from a pentachlorophenol-contaminated soil. Int. J. Syst. Evol. Microbiol. 61, 2231-2237. http://dx.doi.org/10. 1099/ijs.0.025304-0.

Haddadi, A., Shavandi, M., 2013. Biodegradation of phenol in hypersaline conditions by Halomonas sp. strain PH2-2 isolated from saline soil. Int. Biodeterior. Biodegrad. 85, 29-34. http://dx.doi.org/10.1016/j.ibiod.2013.06.005.

Jeong, H., Lee, S., Lee, C., 2013. Biosensors and bioelectronics pump-less static 
microfluidic device for analysis of chemotaxis of Pseudomonas aeruginosa using wetting and capillary action. Biosens. Bioelectron. 47, 278-284. http://dx.doi.org/10. 1016/j.bios.2013.03.031.

Jiang, L., Ruan, Q., Li, R., Li, T., 2013. Biodegradation of phenol by using free and immobilized cells of Acinetobacter sp. BS8Y. J. Basic Microbiol. 53, 224-230. http://dx. doi.org/10.1002/jobm.201100460.

Jianlong, W., Yi, Q., Horan, N., Stentiford, E., 2000. Bioadsorption of pentachlorophenol (PCP) from aqueous solution by activated sludge biomass. Bioresour. Technol. http:// dx.doi.org/10.1016/S0960-8524(00)00041-9.

Johnsen, A.R., Bendixen, K., Karlson, U., 2002. Detection of microbial growth on polycyclic aromatic hydrocarbons in microtiter plates by using the respiration indicator WST-1. Appl. Environ. Microbiol. http://dx.doi.org/10.1128/AEM.68.6.2683-2689. 2002.

Kılıç, N.K., 2009. Enhancement of phenol biodegradation by Ochrobactrum sp. isolated from industrial wastewaters. Int. Biodeterior. Biodegrad. 63, 778-781. http://dx.doi. org/10.1016/j.ibiod.2009.06.006.

Krell, T., Lacal, J., Reyes-Darias, J.A., Jimenez-Sanchez, C., Sungthong, R., Ortega-Calvo, J.J., 2013. Bioavailability of pollutants and chemotaxis. Curr. Opin. Biotechnol. 24, 451-456. http://dx.doi.org/10.1016/j.copbio.2012.08.011.

Lacal, J., Reyes-Darias, J.A., García-Fontana, C., Ramos, J.-L., Krell, T., 2013. Tactic responses to pollutants and their potential to increase biodegradation efficiency. J. Appl. Microbiol. 114, 923-933. http://dx.doi.org/10.1111/jam.12076.

Lanfranconi, M.P., Alvarez, H.M., Studdert, C.A., 2003. A strain isolated from gas oilcontaminated soil displays chemotaxis towards gas oil and hexadecane. Environ. Microbiol. 5, 1002-1008. http://dx.doi.org/10.1046/j.1462-2920.2003.00507.x.

Law, A.M.J., Aitken, M.D., Hill, C., Carolina, N., 2005. Continuous-flow capillary assay for measuring bacterial chemotaxis. Society 71, 3137-3143. http://dx.doi.org/10.1128/ AEM.71.6.3137.

Lei, Y., Chen, W., Mulchandani, A., 2006. Microbial biosensors. Anal. Chim. Acta 568, 200-210. http://dx.doi.org/10.1016/j.aca.2005.11.065.

Lu, D., Zhang, Y., Niu, S., Wang, L., Lin, S., Wang, C., Ye, W., Yan, C., 2012. Study of phenol biodegradation using Bacillus amyloliquefaciens strain WJDB-1 immobilized in alginate-chitosan-alginate (ACA) microcapsules by electrochemical method. Biodegradation 23, 209-219. http://dx.doi.org/10.1007/s10532-011-9500-2.

Marx, R.B., Aitken, M.D., 2000. Bacterial chemotaxis enhances naphthalene degradation in a heterogeneous aqueous system. Environ. Sci. Technol. 34, 3379-3383. http://dx. doi.org/10.1021/es000904k.

Mathialagan, T., Viraraghavan, T., 2009. Biosorption of pentachlorophenol from aqueous solutions by a fungal biomass. Bioresour. Technol. 100, 549-558. http://dx.doi.org/ 10.1016/j.biortech.2008.06.054.

McAllister, K.A., Lee, H., Trevors, J.T., 1996. Microbial degradation of pentachlorophenol. Biodegradation 7, 1-40. http://dx.doi.org/10.1007/BF00056556.

Meng, L., Li, H., Bao, M., Sun, P., 2017. Metabolic pathway for a new strain Pseudomonas synxantha LSH-7': from chemotaxis to uptake of n-hexadecane. Sci Rep 7, 39068.

Middaugh, D.P., Resnick, S.M., Lantz, S.E., Heard, C.S., Mueller, J.G., 1993. Toxicological assessment of biodegraded pentachlorophenol: Microtox ${ }^{\circledast}$ and fish embryos. Arch. Environ. Contam. Toxicol. 24, 165-172. http://dx.doi.org/10.1007/BF01141343.

Murialdo, S.E., Fenoglio, R., Haure, P.M., González, J.F., 2003. Degradation of phenol and chlorophenols by mixed and pure cultures. WaterSA 29, 457-464.

Nisenbaum, M., Sendra, G.H., Cerdá Gilbert, G.A., Scagliola, M., González, J.F., Murialdo, S.E., 2013. Hydrocarbon biodegradation and dynamic laser speckle for detecting chemotactic responses at low bacterial concentration. J. Environ. Sci. 25, 613-625. http://dx.doi.org/10.1016/S1001-0742(12)60020-5.
Nisenbaum, M., Maldonado, E., Arca, J.M., González, J.F., Passoni, L.I., Murialdo, S.E., 2016. Video processing analysis for the determination and evaluation of the chemotactic response in bacterial populations. J. Microbiol. Methods 127, 146-153. http://dx.doi.org/10.1016/j.mimet.2016.06.006.

Pandey, G., Jain, R.K., 2002. Bacterial chemotaxis toward environmental pollutants: role in bioremediation. Appl. Environ. Microbiol. 68, 5789-5795.

Parkinson, J.S., 2007. A "Bucket of Light" for viewing bacterial colonies in soft agar. Methods Enzymol. 423, 432-435. http://dx.doi.org/10.1016/S0076-6879(07) 23020-4.

Paul, D., Pandey, G., Pandey, J., Jain, R.K., 2005. Accessing microbial diversity for bioremediation and environmental restoration. Trends Biotechnol. 23, 135-142. http://dx.doi.org/10.1016/j.tibtech.2005.01.001.

Paul, D., Singh, R., Jain, R.K., 2006. Chemotaxis of Ralstonia sp. SJ98 towards p -nitrophenol in soil. Environ. Microbiol. 8, 1797-1804. http://dx.doi.org/10.1111/j. 1462-2920.2006.01064.x.

Parales, R.E., 2004. Nitrobenzoates and aminobenzoates are chemoattractants for Pseudomonas strains. Appl. Environ. Microbiol. 70, 285-292. http://dx.doi.org/10. 1128/AEM.70.1.285-292.2004.

Pham, H.T., Parkinson, J.S., 2011. Phenol sensing by Escherichia coli chemoreceptors: a nonclassical mechanism. J. Bacteriol. 193, 6597-6604. http://dx.doi.org/10.1128/ JB.05987-11.

Quilty, B., 1998. The Degradation of Phenol and Mono-chlorophenols by a Mixed Microbial Population.

Sarand, I., Österberg, S., Holmqvist, S., Holmfeldt, P., Skärfstad, E., Parales, R.E., Shingler, V., 2008. Metabolism-dependent taxis towards (methyl)phenols is coupled through the most abundant of three polar localized Aer-like proteins of Pseudomonas putida. Environ. Microbiol. 10, 1320-1334. http://dx.doi.org/10.1111/j.1462-2920. 2007.01546.x.

Shannon, C.E., 1948. A mathematical theory of communication. Bell Syst. Tech. J. 27, 379-423. http://dx.doi.org/10.1002/j.1538-7305.1948.tb01338.x.

Shrout, P.E., Fleiss, J.L., 1979. Intraclass correlations: uses in assessing rater reliability. Psychol. Bull. 86, 420-428. http://dx.doi.org/10.1037/0033-2909.86.2.420.

Tolker-Nielsen, T., Brinch, U.C., Ragas, P.C., Bo Andersen, J., Suhhr Jacobsen, C., Soren, M., 2000. Development and dynamics of Pseudomonas sp. Biofilms. J. Bacteriol. 182, 6482-6489. http://dx.doi.org/10.1128/JB.182.22.6482-6489.2000.Updated.

Tso, W., Adler, J., 1974. Negative Chemotaxis in Escherichia coli Negative Chemotaxis in Escherichia coli. 118. pp. 560-576.

United States Environmental Protection Agency, 1980. EPA 440/5-80-065. Ambient Water Quality Criteria for Pentachlorophenol.

Wang, Y., Wang, X., Li, H., Lin, K., Wang, P., Yang, J., Liu, Y., Sun, Z., Fan, L., Wu, Z., 2014. Treatment of high salinity phenol-laden wastewater using a sequencing batch reactor containing halophilic bacterial community. Int. Biodeterior. Biodegrad. 93, 138-144.

Wolski, E.A., Murialdo, S.E., Gonzalez, J.F., 2006. Effect of pH and inoculum size on pentachlorophenol degradation by Pseudomonas sp. Water SA 32, 93-98. http://dx. doi.org/10.4314/wsa.v32i1.5228.

Yang, C.-F., Lee, C.-M., 2008. Pentachlorophenol contaminated groundwater bioremediation using immobilized Sphingomonas cells inoculation in the bioreactor system. J. Hazard. Mater. 152, 159-165. http://dx.doi.org/10.1016/j.jhazmat.2007. 06.102.

Yu, H.S., Alam, M., 1997. An agarose-in-plug method to study chemotaxis in the Archaeon Halobacterium salinarum. FEMS Microbiol. Lett. 156, 265-269. 